\title{
Endosperm condition and the paradox of Ptychococcus paradoxus
}

\author{
Scott Zona
}

\begin{abstract}
Zona, S. (Fairchild Tropical Garden, 11935 Old Cutler Road, Coral Gables, FL 33156-4242, USA. e-mail: szona@fairchildgarden.org). Endosperm condition and the paradox of Ptychococcus paradoxus. Telopea 10(1): 179-185. Endosperm condition, whether homogeneous or ruminate, is an easily-observed character that is widely used in species level taxonomy of palms, although it appears to be a poor indicator of relationships at higher levels. Palms are routinely described as having homogeneous or ruminate endosperms; however, all endosperm ruminations may not be homologous. My experience with the palm genus Ptychococcus (Arecaceae: Arecoideae) suggests that misinterpretations of endosperm variation have led to taxonomic confusion. I have examined herbarium specimens of lowland Ptychococcus and conclude that variation in endosperm condition is continuous, from completely homogeneous to slightly ruminate to deeply ruminate. In the absence of contradictory evidence from other characters, I conclude that the various taxa defined solely by their endosperm condition cannot be maintained and that only one species of Ptychococcus, P. paradoxus, should be recognized from the lowlands of New Guinea. The paradox of $P$. paradoxus lies in the variability of its endosperm, which has been confounding botanists for over a century.
\end{abstract}

\section{Introduction}

Endosperm condition, whether ruminate or homogeneous, has long been recognized as a useful and often diagnostic character state in angiosperms. A ruminate endosperm is characterized by in-growths or invaginations of the endosperm by the seed coat (Bayer \& Appel 1996, Werker 1997). A homogeneous endosperm lacks such in-growths. Obvious examples of ruminate endosperms are found in the seeds of nutmeg, Myristica fragrans Houtt. (Myristicaceae), and betel nuts, Areca catechu L. (Arecaceae).

A recent survey of Angiosperms by Bayer and Appel (1996) found 58 families in which the ruminate endosperm condition is known to occur, and van Balgooy (1997) listed those Malesian seed plants with the ruminate condition (although he also included exalbuminous taxa with convoluted embryos, which are usually termed 'labyrinth seeds'). Prominent on both of those lists is the palm family (Arecaceae). Within the palm family, 51 genera (out of nearly 200) have at least one species with ruminate endosperm, and 23 of these genera occur in the Malesian region (Table 1).

Ruminate endosperm morphology has been used successfully in the classification of some groups, e.g. Annonaceae (van Setten \& Koek-Noorman 1992), but the morphology of endosperm ruminations in palms has not been carefully examined. Although the presence or absence of ruminate endosperm is much used at the species level in palms, it appears to be homoplasious when used for higher level classification. Ruminate endosperm occurs in four different subfamilies of palms and numerous tribes and subtribes (Table 1), an observation suggesting that it has evolved and/or been lost many times in the course of palm evolutionary history. 
Table 1. Occurrence of ruminate endosperm within the Arecaceae (Uhl \& Dransfield 1987, with modifications from Dowe \& Cabalion 1996, Barrow 1998, Uhl and Dransfield 1999 and Dransfield et al. 2000). Genera occurring in Malesia are marked with an asterisk (*).

\author{
CORYPHOIDEAE \\ Chamaerops \\ Copernicia \\ Chuniophoenix p.p. \\ Kerriodoxa* \\ Phoenix p.p.* \\ Medemia \\ Satranala \\ CALAMOIDEAE \\ Korthalsia p.p. * \\ Daemonorops* \\ Calamus p.p.* \\ Raphia \\ CEROXYLOIDEAE \\ Synechanthus \\ ARECOIDEAE \\ Caryota p.p. * \\ Wettinia p.p. \\ Reinhardtia p.p. \\ Dypsis p.p. \\ Euterpe p.p. \\ Prestoea p.p. \\ Neonicholsonia \\ Oenocarpus p.p. \\ Archontophoenix \\ Laccospadix
}

\author{
Calyptrocalyx p.p.* \\ Drymophloeus p.p.* \\ Normanbya \\ Adonidia* \\ Ptychosperma p.p. * \\ Ptychococcus p.p. * \\ Loxococcus \\ Lemurophoenix \\ Siphokentia* \\ Hydriastele p.p.* \\ Gulubia p.p.* \\ Nenga* \\ Pinanga p.p.* \\ Areca* \\ lguanura p.p.* \\ Heterospathe p.p.* \\ Rhopaloblaste* \\ Dictyospermum \\ Actinorhytis* \\ Physokentia p.p.* \\ Oncosperma* \\ Verschaffeltia \\ Roscheria \\ Phoenicophorium \\ Nephrospermum \\ Beccariophoenix \\ Syagrus p.p. \\ Lytocaryum p.p. \\ Polyandrococos
}

\section{Development of ruminations}

The ruminate endosperms of palms have been the subject of several anatomical studies, although the topic is not yet exhausted. Periasamy (1962) classified ruminate palm seeds as 1) the Annona type: possessing localized meristematic activity in a multi-layered seed coat that produces in-growths in the endosperm, or 2) the Myristica type, which is similar but the in-growths have vascular tissue or are subadjacent to vascular tissue. Examples of the Annona type include Caryota and Heterospathe (Werker 1997); examples of the Myristica type include Adonidia and Bentinckia (Murray 1971, Padamanabham \& Regupathy 1981). Examples of Periasamy's other five types of ruminate endosperm, which differ in the number of integument layers and layers of the seed coat, have not been found in the Arecaceae.

Werker (1997) noted additional variation in the development of palm seed ruminations. The endosperm of some palm seeds, at an early stage of development becomes quiescent while the seed coat and integuments develop irregularities. When at a later stage, the endosperm again commences growth, it fills in the around the seed coat. One might say that the seed coat leads, and the endosperm follows. In contrast, ruminations in other palms develop as a result of unequal and localized cell division of the nucellus (megagametophyte). The nucellus throws the seed coat into irregular folds, and then the seed coat hardens. As the embryo sac enlarges and absorbs the nucellus, it conforms to the shape of the seed coat. In this case, the nucellus leads, and the seed coat follows. 


\section{Endosperm condition and palm taxonomy}

Until well into the $20^{\text {th }}$ century, endosperm condition was used at the generic level in palm classification. In other words, pairs of genera that differed primarily in endosperm condition were recognized (Hooker 1883; Drude 1887; Burret 1953). Examples of these generic pairs are Phloga (ruminate) and Neophloga (homogeneous), Coleospadix (ruminate) and Drymophloeus (homogeneous), Rhyticocos (ruminate) and Syagrus (homogeneous) and Jessenia (ruminate) and Oenocarpus (homogeneous). In all of these examples, the generic pairs are now recognized as congeneric (Uhl \& Dransfield 1999). A broadening of generic concepts allowed the recognition of genera that include species with ruminate endosperms alongside species with homogeneous endosperms. Of the 51 genera with ruminate endosperms listed in Table 1223 genera also include species with homogeneous endosperms.

Endosperm condition, however, is sometimes not so easily interpreted, and the dichotomy between ruminate and homogeneous is not always clear-cut. The following example presents evidence that, in the case of Ptychococcus paradoxus (Sheff.) Becc., endosperm condition varies continuously from homogeneous to ruminate, and overemphasis on this one character has led to taxonomic confusion. I conclude that, for Ptychococcus paradoxus, the species concept must be broadened to allow this single species to accommodate both homogeneous and ruminate endosperms.

\section{The case of Ptychococcus paradoxus}

The type specimen of Ptychococcus paradoxus was collected by J. E. Teijsmann in July, 1871, from New Guinea. He collected only fruits, which he brought back to the Buitenzorg (now Bogor) Botanic Garden for propagation. One fruit or endocarp was the basis for Scheffer's (1876a) description; later descriptions of vegetative characters were based on juvenile plants grown from the seeds of these fruits. When Scheffer (1876a; p. 53) proposed the name Drymophloeus ? paradoxus, he described the endosperm as 'subaequalibe' (sub-homogeneous), yet just a few lines later, he wrote that the endosperm was not ruminate. At the time, Drymophloeus was thought to comprise only species with homogeneous endosperms. In a consecutive publication (Scheffer $1876 \mathrm{~b}$, p. 121), he suggested that his D. paradoxus may belong to the same genus as Ptychosperma capitis-yorkii H. Wendl. \& Drude [= P. elegans (R. Br.) Blume], a taxon noteworthy for its deeply ruminate endosperm. By pages 155 and 156, Scheffer (1876b) was calling his taxon Ptychosperma paradoxa and admitting that his first description was incorrect, that his type was in poor condition and difficult to interpret and that additional material had ruminate endosperms.

How did Scheffer come to have better material of this taxon in the course of 102 pages? The additional material then at his disposal was produced on plants grown from Teijsmann's seeds (Scheffer 1876b, p. 156). Scheffer's (1876a) work, including the description of Drymophloeus ? paradoxus on p. 53, described the interesting plants brought back by Teijsmann from New Guinea. It was likely prepared for publication in 1871, immediately upon receiving Teijsmann's collections, perhaps with the intention of including it in his first publication on Areceae (Scheffer 1871). For reasons unknown, publication of the work was delayed, and it did not appear until 1876. Rather than rewrite the description drafted earlier, Scheffer published it as it stood and later (1876b) emended his description. By that time, the seeds collected by Teijsmann and planted in the botanic garden had grown and provided additional material for Scheffer's examination. 
In December 1999, a search of the Herbarium Bogoriense (BO) for the type specimen of Ptychococcus paradoxus revealed a bag of fruits among the carpological collections bearing Teijsmann's name (J. Dransfield, pers. com.). The seeds of the fruits showed, according to Dransfield, 'absolutely no signs of rumination'. This specimen, however, cannot be the type, as Scheffer (1876b) said he had only one fruit and that this was in such bad condition he had difficulty in interpreting the endosperm condition. In addition, the specimen located by Dransfield does not match the protologue (Scheffer 1876a) for this species. The type of P. paradoxus has not yet been located. Perhaps Scheffer destroyed the specimen, believing it to be in poor condition and unrepresentative.

Upon describing a new species, Ptychococcus arecinus (Becc.) Becc. (as Ptychosperma arecina Becc.), Beccari (1877) noted that the endosperm of P. paradoxus was less ruminate than that of his new species. Clearly, the degree of endosperm rumination was influencing species concepts and taxonomic decisions for Beccari at a time when the endosperm condition was often taken to have generic-level significance. For Beccari, with only a handful of specimens to compare, differences in endosperm condition, together with supposed differences in trunk and andreocium characters, seemed highly significant.

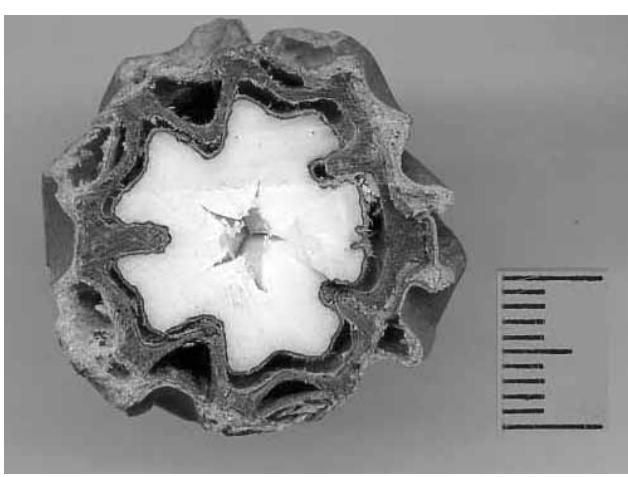

a

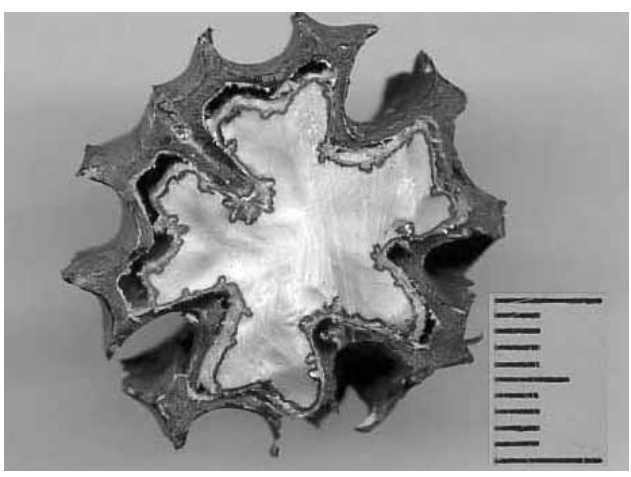

C

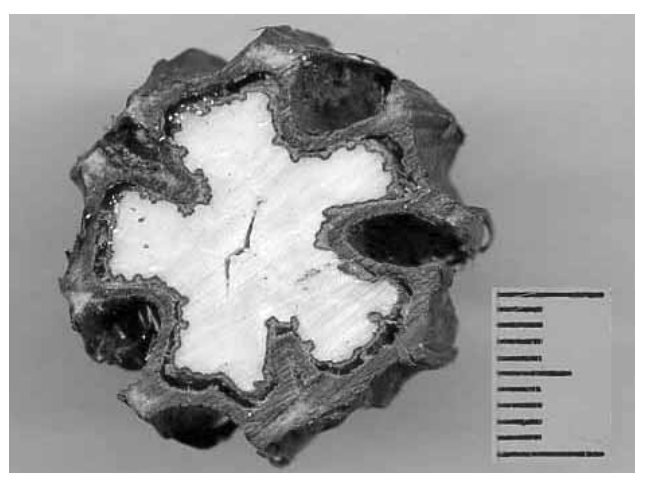

b

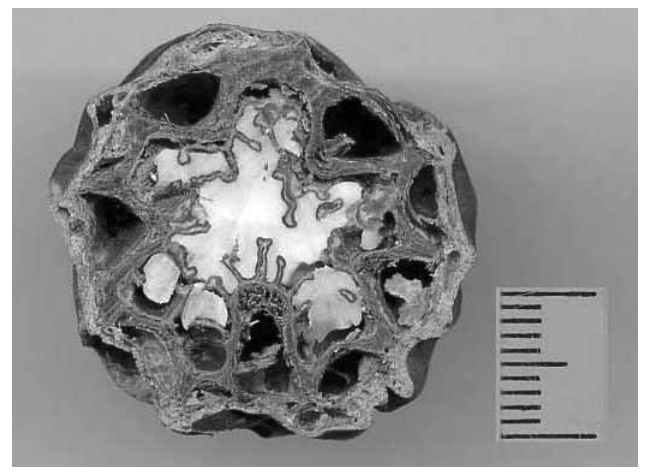

d

Fig. 1. Transverse sections through dried fruits and seeds of Ptychococcus paradoxus showing variation in endosperm condition. a, endosperm homogeneous (with slight intrusion visible along rapheal side of seed, at right); $\mathbf{b}$, slight marginal rumination; $\mathbf{c}$, slight rumination; $\mathbf{d}$, profoundly ruminate endosperm. (a from Baker 597; b from Raffill s.n.; c from Furtado X-D-32; d from Heatubun CH195. All specimens at K). Scale bars $=10 \mathrm{~mm}$. 
As new material came to hand from collectors in Papua New Guinea, additional species were described. In the early years of the $20^{\text {th }}$ century, Beccari described three taxa, and Burret added two more, bringing to seven the number of taxa in the genus. Burret (1939) used endosperm condition to subdivide the genus into two sections, one ruminate and the other homogeneous.

Pichi-Sermoli (in Beccari \& Pichi-Sermoli 1955) cast doubt on the usefulness of the endosperm character. He did not accept the subdivisions of Burret (1936), believing that there was overlap between the two subgenera and that species with superficially ruminate endosperm would be difficult to classify in Burret's sections. Pichi-Sermoli is the first botanist to question the usefulness of endosperm condition in classifying palms and to suggest that the distinction between the two conditions was not black and white. He offered no reason for his apostasy, but perhaps his careful examination of seeds, especially noticing those with superficial ruminations, which most botanists would call 'homogeneous', led him to his new stance.

After examining a series of 20 specimens (many more than were available to Scheffer, Beccari or Pichi-Sermoli), I too began to doubt the usefulness of endosperm condition as a means of distinguishing species in Ptychococcus. Specimens appearing identical in vegetative and floral features differed only in the condition of the endosperm (Figs. 1a-d), from completely homogeneous (Pullen 1077 at A or Baker 597 at K, Fig. 1a) to slightly ruminate around the edges (Raffill s.n. and Furtado s.n. at K, Figs. 1b and 1c, respectively) to strongly ruminate (Heatubun CH195 at K, Fig. 1d). Previously recognized differences in stamen number evaporated when a large series of specimens was examined; likewise, stem diameter appears to be a highly plastic character, depending on local growing conditions. I saw no way in which these specimens can be easily and unambiguously separated into species groups. Therefore, I believe that specimens cannot be unambiguously assigned to Burret's subgenera and that his classification should be abandoned. Available evidence suggests the lowland species of Ptychococcus should be recognized as a single species, P. paradoxus.

\section{An end to endosperm condition as a taxonomic character?}

The recognition of just one species of Ptychococcus in lowland New Guinea brings an end to some of the taxonomic confusion surrounding these palms. Moreover, this taxonomic disposition resolves the proliferation of names for every endosperm variant. Should other groups of palm species be re-examined to determine if they too should include both ruminate and homogeneous endosperms?

The endosperm condition of Ptychococcus lepidotus H. E. Moore from the highlands of New Guinea is also controversial. Few seed specimens of P. lepidotus are available for study, so the degree to which its endosperm condition varies is unknown. Moore (1965), in describing the species, noted 'shallow marginal ruminations on the lobes and a deep intrusion on the rapheal lobes'. Ferrero (1996) reported that the endosperm was ruminate. However, one specimen (Hoogland 9033 at K and L) appears to have a homogeneous endosperm. Additional material of $P$. lepidotus is greatly desired.

The variable endosperm condition described for Ptychococcus is not unique in the family. Another palm, Synechanthus fibrosus (H. Wendl.) H. Wendl., is a species in which the endosperm condition is variable. Synechanthus is a genus of two species from Mexico and Central America allied to Chamaedorea and Hyophorbe. Moore (1971) described $S$. fibrosus as having a 'homogeneous or minutely and marginally ruminate endosperm'. 
Henderson and Galeano (1996), in a revision of Prestoea, a genus of Central and South America, described the endosperm of P. pubens H. E. Moore as 'lightly (then almost homogeneous) to deeply ruminate'. In the same publication, they described $P$. longepetiolata (Oersted) $\mathrm{H}$. E. Moore as comprising three varieties. Two varieties have ruminate endosperms, but $P$. longepetiolata var. cuatrecasasii (H. E. Moore) Henderson \& Galeano is said to have a homogeneous endosperm.

Do these examples sound the death knell for the usefulness of endosperm condition in the classification of palms? Not at all; endosperm condition will continue to be an important and useful character. It is a helpful 'spot-character' (van Balgooy 1997) and an easily-observed character for use in keys. Moreover, more detailed study of endosperm condition may reveal previously overlooked characters that may prove useful in phylogenetic classifications. Nevertheless, the taxonomic history of Ptychococcus paradoxus is a cautionary tale. The paradox of P. paradoxus lies in the variability of its endosperm, which has been confounding botanists for over a century.

\section{Acknowledgments}

I thank Dr Carl Lewis for his helpful comments on an earlier version of this manuscript and Johan B. Mols for his assistance with Annonaceae literature. I am especially grateful to Meesha Patel, of the Royal Botanic Gardens, Kew, for scanning the specimens thereby providing the illustrations for this paper.

\section{References}

Barrow, S.C. (1998) A monograph of Phoenix L. (Palmae: Coryphoideae). Kew Bull. 53: 513-575.

Bayer, C. \& O. Appel. (1996) Occurrence and taxonomic significance of ruminate endosperm. Bot. Rev. 62: 301-310.

Beccari, O. (1877) Le specie di palmae raccolte alla nuova guinea da O. Beccari e dal medesimo adesso descritte, con note sulle specie dei paesi circomvecini. Malesia 1: 9-96.

Beccari, O. \& R.E.G. Pichi-Sermoli. (1955) Subfamiliae arecoidearum palmae gerontogeae: Tribuum et generum conspectus. Webbia 11: 1-187.

Burret, M. (1939) Palmae gesammelt in Neu Guinea von L. J. Brass. J. Arnold Arbor. 20: 187-212.

Burret, M. (1953) Sytematische Übersicht über die Gruppen der Palmen. Willdenowia 1: 59-74.

Dowe, J.L. \& P. Cabalion. (1996) A taxonomic account of Arecaceae in Vanuatu, with descriptions of three new species. Austral. Syst. Bot. 9: 1-60.

Dowe, J.L. \& M.D. Ferrero. (2001) Revision of Calyptrocalyx and the New Guinea species of Linospadix (Linospadicinae: Arecoideae: Arecaceae). Blumea 46: 207-251.

Dransfield, J., G.G. Hambali, R.A. Maturbongs, \& C.D. Heatubun. (2000) Caryota zebrina. Palms 44: $170-174$.

Drude, O. (1887) ['1889'] Palmae, pp. 1-93 in A. Engler \& K. Prantl (eds) Die naturlichen Pflanzenfamilien. II (3).

Ferrero, M. D. (1996) Ptychococcus lepidotus: In from the cold? A promising palm from the highlands of New Guinea. Palms \& Cycads (Austral.) 52/53: 48-54.

Henderson, A. \& G. Galeano. (1996). Euterpe, Prestoea, and Neonicholsonia (Palmae). Flora Neotropica 72: $1-90$.

Hooker, J. D. (1883) Palmae, pp. 870-948 in G. Bentham \& J. D. Hooker, Genera Plantarum, vol. 3. (Reeve \& Co.: London).

Moore, H. E., Jr. (1965) Ptychococcus lepidotus-A new species from New Guinea. Principes 9: 10-13.

Moore, H. E., Jr. (1971) The genus Synechanthus (Palmae). Principes 15: 10-19.

Murray, S. G. (1971) The developmental anatomy of certain palm fruits. Unpublished Ph.D. dissertation, Cornell University.

Padmanabhan, D. \& D. Regupathy. (1981) Studies on Bentinckia condapanna: I. The fruit and the seed. Principes 25: 172-177. 
Periasamy, K. (1962) The ruminate endosperm: development and type of rumination. Pp. 62-74 in Plant Embryology: A Symposium. (CSIR: New Delhi).

Scheffer, R. H. C. C. (1871) Sur quelques palmiers du groupe des Arécinées. Nat. Tijdschr. Ned. Ind. 32: 149-193.

Scheffer, R. H. C. C. (1876a) Énumeration des plantes de la Nouvelle-Guinée, avec déscription des espèces nouvelles. Ann. Jard. Bot. Buitenzorg 1: 1-60.

Scheffer, R. H. C. C. (1876b) Sur quelques palmiers du groupe des Arécinées. Deuxième partie. Ann. Jard. Bot. Buitenzorg 1: 103-164.

Uhl, N. W. \& J. Dransfield. (1987) Genera palmarum: A classification of palms based on the work of Harold E. Moore, Jr. (L. H. Bailey Hortorium and the International Palm Society: Lawrence, Kansas).

Uhl, N. W. \& J. Dransfield. (1999) Genera Palmarum after ten years. Mem. New York Bot. Gard. 83: 245-253.

van Balgooy, M.M. J. (1997) Malesian seed plants. Vol. 1-Spot-characters. (Rijksherbarium: Leiden). van Setten, A.K. \& J. Koek-Noorman. (1992) Fruits and seeds of the Annonaceae: Morphology and its significance for classification and identification. Bibliotheca Botanica 142: 1-101.

Werker, E. (1997) Seed anatomy. Encyclopedia of Plant Anatomy, Bd. 10, Teil 3. 
